\title{
Liquidity Moderating the Effect of Production Resources, Investment Decisions and Corporate Social Responsibility on Corporate Performance
}

\author{
Roristua Pandiangan $^{1 *} \quad$ Etty Murwaningsari ${ }^{2}$ \\ 1.Students of the Economic Doctoral Program in Accounting Concentration, Trisakti University, Jakarta, \\ Indonesia \\ 2.Trisakti University Faculty of Economics and Business, Jakarta, Indonesia
}

\begin{abstract}
The purpose of this study investigates the effect of simultaneous and partial production resources, investment decision, and corporate social responsibility on company performance and investigate liquidity as a moderating variable on the effect of production resources, investment decisions, corporate social responsibility on corporate performance.The population of this research is 148 manufacturing companies listed on the Indonesia Stock Exchange, the selection of research samples using purposive sampling method with criteria revealed the realization of CSR expenses in the 2016-2018 period so that 77 manufacturing companies were obtained with 3 years of observation and 231 years of corporate data were obtained, data analysis method used multiple regression analysis and moderate regression analysis (MRA).Research findings: 1) Production Resources, Investment Decisions, Corporate Social Responsibility simultaneously influence and significantly affect Corporate Performance. 2) Production Resources have a negative and significant effect on Corporate Performance. 3) Investment Decisions have a positive and significant effect on Corporate Performance. 4) Corporate Social Responsibility have a positive and significant effect to corporate performance. 5) Liquidity moderates the effect of production resources to corporate performance. 6) Liquidity does not moderate the effect of investment decisions to corporate performance. 7) Liquidity does not moderate the effect of corporate social responsibility on corporate performance.
\end{abstract}

Keywords: Corporate Performance, Production Resources, Investment Decisions, Corporate Social Responsibility, Liquidity.

DOI: $10.7176 /$ RJFA/10-20-03

Publication date:October $31^{\text {st }} 2019$

\section{Introduction}

Burger King, Unilever, Nestle, Kraft Food stop buying palm oil produced by the Sinar Mas Group where the Sinar Mas group customers assume that the Sinar Mas Group is destroying tropical forests to open up oil palm plantations. Funding originating from foreign banks for the divestment of $51 \%$ of PT. Freeport Indonesia by PT. Indonesia Asahan Aluminum is hampered due to environmental issues, on the other side there are companies that do not deal with the obstacles in conducting the acquisition process such as MUFG Bank Ltd acquired Bank Danamon through Bank of Tokyo Mitsubishi UFJ, Ltd. (BTMU) through 2 stages and BCA took a corporate action by buying Bank Royal Indonesia. Decisions taken and implemented by each entity to maximize profit achievement and minimize the occurrence of business risks in the future.

Usually an entity seeks to keep maximizing the achievement of profit as the main goal and one measure of company performance, on the other side, it must still consider to the environmental and social conditions that are directly or indirectly related to the operations of the entity. Stewarship Theory says that management overrides his personal interests and chooses the interests of the organization so as to create good cooperation and mutual trust between management and the owner (agent costs are reduced, there is no asymmetrical information) in carrying out business operations (Donaldson \& Davis, 1991; Zhang, et.al., 2017; Subramanian, 2018; Chrisman, 2019; Schillemans \& Bjurstrøm, 2019).

Production cost efficiency and the application of production cost control methods can increase profits (Dahan and Srinivasan, 2011; Muthukumar and Nisha, 2014; Qudah and Hroot, 2017). This is done by the management of the entity to safeguard investment, productivity and efforts to maximize profits.

The decision for investment generally looks at the realization of past income or profits, company growth is linked to research investment, development (Coad and Rao, 2012, Coad and Grassano, 2018), linked to profit and debt (Aivazian, 2005; Franklin and Muthusamy, 2011; Coban, 2014; Muzaffar, 2015; Danso, et.al., 2017). Majanga (2016) states that capital expenditure is related to profit, asset growth and asset structure related to ROA and ROE (Inyiama, et.al, 2017; Mwaniki and Omagwa, 2017) on the other side the asset structure does not affect ROE and operating profit (Okwo, et.al., 2012; Al Ani, 2014 ).

CSR increases investment efficiency (Zhong and Gao 2017; Samet and Jarboui, 2017; Benlemlih and Bitar, 2018; Cook, et.al., 2018). On the other side, CSR is a source of conflict in internal companies (Kruger, 2015), CSR reduces intangible assets (Branco and Rodriguez, 2006), CSR increases the company's operational costs 
(McWilliams, 2006; Barnet, 2016), CSR influences investment and decreases company value because of inappropriate use of resources (Vance, 1975).

Liquidity is very sensitive and can be an obstacle to investments made by business entities (Hoshi, et. Al., 1991; Audretsch and Elston, 2000; Munoz, 2013; Jafari, 2014; Ogawa, 2015). Therefore, stability of company liquidity is a strength and / or weakness for management to finance company operations, company investment and corporate social responsibility (CSR).

The purpose of this study investigates the effect of simultaneous and partial production resources, investment decision, and corporate social responsibility (CSR) on corporate performance and investigate liquidity as a moderating variable on the effect of production resources, investment decisions, corporate social responsibility (CSR) on corporate performance.

The novelty in this study as far as the author's observation lies in measuring the variables of production resources by comparing the cost of goods sold with sales so that it is known the productivity of the company. The contribution of this study consists of : 1) this study is present to fill the narrow gap left by previous research, namely connecting production resources with measurements that are different from corporate performance. 2) this study is present to fill the differences in the results of previous studies by measuring different earnings and different data sources by linking investment decisions with corporate performance. 3) this research is present to reinvestigate the relationship between corporate social responsibility (CSR) and profit in the context of evidence in Indonesia.

This research is divided into 5 sections consisting of Introduction, Literature Review and Development of Research Hypotheses, Research Methods, Research Findings, Conclusions.

\section{Literature review}

The Grand theory used is Stewarship Theory, Stewarship's theory was first put forward by Donaldson and Davis (1991), the core of this theory is that the owner and management work together, transparently to achieve the goals of the organization and the owner, on the other side the management overrides his personal interests, one concrete manifestation of organizational goals can be seen through the performance of the company.

Corporate performance can be seen from two sides, namely financial performance and non-financial performance. This research focus on financial performance, namely from a profit perspective, The ratio of net profit margin is used to measure financial performance (Borhan, et. Al., 2013; Olatunji et al., 2014). Net profit margin is one of the important indicators to assess the company's performance in terms of finance.

Production resources in manufacturing companies generally consist of 1) Direct raw materials. 2) Direct labor. 3) Additional production costs commonly called Overhead. Noreen and Soderstorm (1994) say that based on activity, costs are divided into fixed costs and variable costs. Sales do not always increase or decrease so the company still produces in a predetermined capacity, Balakrishnan et al. (2004) say companies do not reduce resources immediately due to decreased sales. The report on cost of goods sold has the potential to be the place where management conducts earnings management, Fan and Liu (2016) find that managers will be wrong classify cost realization in the focus of the ratio of gross profit margin or pursue other incentives.

Investors' investment decisions (can be in the form of private individuals, companies, the Government) invest their money by allocating their money into other assets that are expected to provide benefits in the future. Stulz (1990) states that financing policies and dividends reduce agency costs for companies that have advantages or disadvantages of investment, "successful companies grow by reinvesting in business, producing their assets through profitable operations "(Harrison, Jr., et.al., 2013: 599), "Companies invest in debt and equity of other companies for various reasons. A main reason is to get a return on their excess cash "(Albrecht, et. Al., 2011: 554). Fixed assets are long-term or relatively permanent assets (Warren, et.al., 2014:174), In general, current assets consist of cash and cash equivalents, short term / temporary investments, accounts receivable, inventories, expenditures which are recorded as assets (Weygandt, et.al., 2012: 388, Albrecht, et.al., 2011: 554, Wild, 2011: 292, Williams, et. Al., 2012: 340, Needles, et. Al., 2014: 91). On the other side, Intangible assets are also considered long-term assets "(Slater, 2013: 592).

The general description of environmental compensation referred to in this study is the form of the responsibility of the business entity in its operations towards the environment of the business entity. CSR is a reflection of the responsibility of business entities for the environment that are directly and indirectly related to the operations of the company. The emergence of the term CSR is due to the problem of competition in life, control of resources, social welfare caused by exploitation of resources by business entities. This problem is always addressed to the Government because the Government is responsible for justice, welfare in the community. Companies to adopt CSR must be costly (Pagano and Volpin 2005; Cronqvist, et.al., 2009; Kruger, 2015), these costs can be in the form of rehabilitation of damaged nature, maintenance of animals whose habitat is damaged, helping the community to improve the economy, buying environmentally friendly equipment, buying equipment for processing waste. In short, a business entity cannot ignore environmental changes due to the operation of a business entity. 
The availability of assets that can be immediately converted into cash and cash equivalents is the concern of the owner and management of the company, this is due to running the company's operations and so does company investment that requires cash and cash equivalents. Corporations financed their operations sourced from shortterm debt, long-term debt, own capital (Warrant, et. Al., 2014: 626), liquidity is needed to grow the company while in the market. The company's growth can be seen from the side of employees and sales (Coad and Grassano, 2018), Growth can be defined in terms of generating income, adding value, and expanding in terms of volume from business (Gupta et.al., 2013). Jensen (1986) states that if the net income which has changed to net cash flow is not distributed, it will be reinvested by the manager.

Conceptual framework that shows the relationship between research variables can be seen in the following figure :

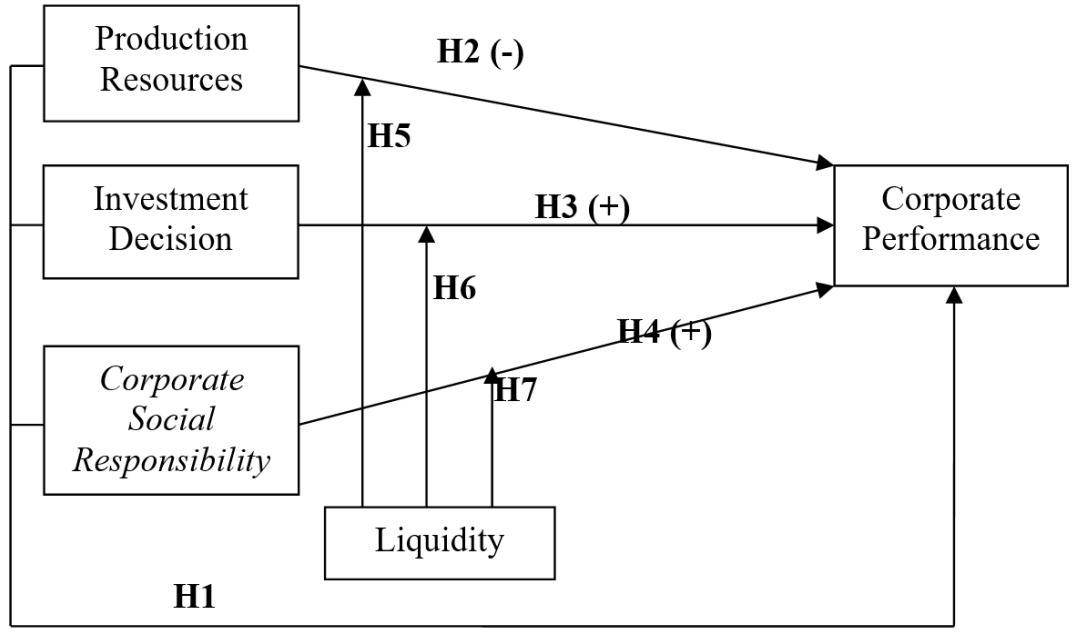

Figure1. Conceptual Framework

\subsection{Development of Research Hypotheses}

Production resources, investment decisions and corporate social responsibility are 3 variables that are inseparable from the performance of companies, especially manufacturing companies listed on the Indonesian stock exchange. Production resources are used to determine the productivity level of manufacturing companies during the production process, investment decisions are used to determine the level of allocation of company assets used to produce products needed by consumers, Corporate social responsibility (CSR) is used to determine the level of concern of the company towards the corporate environment as a form of accountability in minimizing the operational impact of the company. Therefore, the hypothesis set is as follows:

H1: Production Resources, Investment Decisions, Corporate Social Responsibility have a together effect on the Corporate Performance.

Production resources are costs that can be controlled effectively and efficiently in the production process so they can increase profits (Dahan and Srinivasan, 2011; Muthukumar and Nisha, 2014; Qudah and Hroot, 2017). Realization of production resources will be a burden in the company's operations summarized in the cost of sales report, so as to reduce the company's profits. Therefore, the hypothesis set is as follows:

\section{H2: Production Resources have a negative effect on Corporate Performance.}

Majanga (2016) says capital expenditure is related to profit. Growth of current assets and non-current assets, asset structure is related to profit seen from the side of ROA and ROE (Inyiama, et.al, 2017; Mwaniki and Omagwa, 2017), on the other side the asset structure does not have an impact on profit seen from the side of ROE and operating profit (Okwo, et. al., 2012; Al Ani, 2014). Increasing the quality and quantity of fixed assets caused by innovation, new findings, efficiency of asset performance in creating products can increase company profits. Therefore, the hypothesis set is as follows:

H3: Investment Decisions have a positive effect on Corporate Performance.

CSR increases investment efficiency (Zhong and Gao 2017; Samet and Jarboui, 2017; Benlemlih and Bitar, 2018; Cook, et.al., 2018), on the other hand CSR is a source of conflict within the company (Kruger, 2015), CSR reduces intangible assets (Branco and Rodriguez, 2006), CSR increases company operational costs (McWilliams, 2006; Barnet, 2016), CSR influences investment and decreases firm value due to improper use of resources (Vance, 1975). CSR as a means of sharing companies with the corporate environment can reduce the conflict of interest of the company and its environment so that it can prevent or reduce the occurrence of the company's operating expenses, on the other side CSR increases the company's operational expenses and reduces profits or increases losses for the company thereby reducing the company's investment opportunities, CSR realization in 
manufacturing companies in Indonesia is still relatively low when compared to the operating expenses of companies that arise in the event of a conflict of interest such as a lawsuit. Therefore, the hypothesis set is as follows:

\section{H4: Corporate Social Responsibility has a positive effect on corporate performance.}

Corporations financed their operations sourced from short-term debt, long-term debt, own capital (Warrent, et. Al., 2014: 626). Therefore, companies that have good liquidity stability have a high chance to invest now or in the future. Jensen (1986) states that if the net income which has changed to net cash flow is not distributed, it will be reinvested by the manager. Adequacy of company liquidity becomes a powerful weapon for companies to maintain the survival of the company. Therefore, the hypothesis set is as follows:

H5: Liquidity moderates the effect of production resources on corporate performance.

In other studies company growth is associated with profitability (Coban, 2014), other studies leverage is linked to investment (Aivazian, 2005; Franklin and Muthusamy, 2011; Muzaffar, 2015; Danso, et. Al., 2017). Liquidity is sensitive, an obstacle to investment by business entities (Hoshi, et. Al., 1991; Audretsch and Elston, 2000; Munoz, 2013; Jafari, 2014; Ogawa, 2015), to meet the adequacy of company liquidity needed to finance investments in the form of assets, the company can utilize internal and external funds of the company. Adequacy of company liquidity becomes a powerful weapon for companies to make new investments, increase investment. Therefore, the hypothesis set is as follows:

H6: Liquidity moderates the effect of investment decisions on corporate performance.

Comparison of CSR realization with the realization of sacrifices due to company conflicts with the environment is one of management's considerations in creating the company's operational effectiveness and efficiency, in general, the realization of CSR in the form of money spent is relatively smaller than the cost of handling corporate conflicts with their environment. The relatively smaller realization of CSR is a powerful weapon for companies to save the costs of handling conflicts that will arise so that the company is able to maximize profits. Therefore, the hypothesis set is as follows:

H7: Liquidity moderates the effect of corporate social responsibility on corporate performance.

\section{Research methods}

The population of this research is 148 manufacturing companies listed on the Indonesia Stock Exchange, the selection of research samples using purposive sampling method with criteria revealing the realization of CSR expenses in the 2016-2018 period (although only one year) so that 77 manufacturing companies were obtained with 3 years of observation and 231 firm years data were obtained, Data analysis method used multiple regression analysis and moderate regression analysis (MRA).

The net profit margin ratio is used to measure financial performance, the net profit margin ratio can be measured by comparing net income with sales (Borhan, et. Al., 2013; Olatunji et al., 2014).

Production resources are resources used in the production process and reported in the cost of goods sold report (Fan and Liu, 2016). Production resources are measured by comparing the cost of goods sold with sales.

Investment decisions referred to in this study are investment realization allocation decisions contained in the company's financial statements (already recognized based on applicable financial accounting standards). Investment decisions are measured by comparing non-current assets / fixed assets with total assets (Inyiama, et.al, 2017; Mwaniki and Omagwa, 2017).

The general description of corporate social responsibility referred to in this study is the form of the responsibility of a business entity in its operations towards the environment of a business entity, the responsibility of this business entity is known as CSR. CSR is measured by a dummy system where the company that publishes the value of CSR realization in the annual report is given a value of 1 and other is given a value of 0 (Timbate and Park, 2018).

Liquidity is the level of the company's ability to fulfill short-term liabilities and at the same time financing the company's operations. Liquidity can be measured by comparing current assets with current liabilities (Jensen, 1986; Warren, et. al., 2014).

\section{Research Findings}

The description of each research variable can be seen in the descriptive statistics table as follows: 
Table 4.1. Descriptive Statistics

\begin{tabular}{|l|r|r|r|r|r|r|r|}
\hline Name & \multicolumn{1}{|c|}{$\mathrm{N}$} & Minimum & Maximum & \multicolumn{1}{c|}{ Sum } & Mean & Std.Deviation & Variance \\
\hline Production Resources & 231 & .26 & 16.78 & 196.56 & .8509 & 1.06490 & 1.134 \\
\hline Investment Decision & 231 & .04 & .97 & 113.11 & .4897 & .19959 & .040 \\
\hline CSR & 231 & .00 & 1.00 & 210.0 & .9091 & .28810 & .083 \\
\hline Liquidity & 231 & .01 & 102.00 & 593.90 & 2.5710 & 9.22675 & 85.133 \\
\hline $\begin{array}{l}\text { Corporate } \\
\text { Performance }\end{array}$ & 231 & -43.46 & .45 & -34.68 & -.1501 & 2.86535 & 8.210 \\
\hline Valid N (listwise) & 231 & & & & & & \\
\hline
\end{tabular}

Source: Data processed (SPSS 20)

Based on the table above, it is known that the dependent variable is Corporate Performance has a minimum value of -43.46 and a maximum value of 0.45 , the total value of -34.68 with an average value of -1.501 with a standard deviation value of 2.86535 and a variance value of 8.210. Furthermore, it is known that the independent variable is 3, namely Production Resources, Investment Decisions, Corporate Social Responsibility (CSR), and it is known that there are 1 moderating variables, namely Liquidity.

Production Resources have a minimum value of 0.26 and a maximum value of 16.78 , the total value of 196.56 with an average value of 0.8509 with a standard deviation value of 1.06490 and a variance value of 1.134 . Investment Decision has a minimum value of 0.04 and a maximum value of 0.97 , the total value of 113.11 with an average value of 0.4897 with a standard deviation value of 0.19959 and a variance value of 0.40 . Corporate Social Responsibility has a minimum value of 0.00 and a maximum value of 1.00 , the total value of 210.00 with an average value of 0.9091 with a standard deviation value of 0.28810 and a variance value of 0.083 . Liquidity has a minimum value of 0.01 and a maximum value of 102.00, the total value of 593.90 with an average value of 2.5710 with a standard deviation value of 9.2675 and a variance value of 85.133.

Table 4.2. Model Summary

\begin{tabular}{|l|l|r|r|r|l|}
\hline Model & R & R Square & Adjusted R Square & Std. Error of the Estimate & Note \\
\hline 1 & $.993^{\mathrm{a}}$ & .985 & .985 & .35021 & \# \\
\hline 1 & $.995^{\mathrm{a}}$ & .991 & .990 & .28075 & $\#$ \# \\
\hline 1 & $.190^{\mathrm{a}}$ & .036 & .023 & 2.83154 & \# \# \# \\
\hline 1 & $.032^{\mathrm{a}}$ & .001 & -.012 & 2.88271 & \# \# \# \# \\
\hline
\end{tabular}

Source: Data processed (SPSS 20)

Where :

\# Predictors: (Constant), CSR, INVESTMENT DECISIONS, PRODUCTION RESOURCES

\# \# Predictors: (Constant), INTERACTION X1 * Z, PRODUCTION RESOURCES, LIQUIDITY

\# \# \# Predictors: (Constant), INTERACTIONS X2 * Z, INVESTMENT DECISIONS, LIQUIDITY \# \# \# \# Predictors: (Constant), INTERACTION X3 * Z, CSR, LIQUIDITY

Production resources, investment decisions, corporate social responsibility together related to corporate performance and $98.5 \%$ able to explain corporate performance and $1.5 \%$ explained by variables not examined in this study.

Production resources, liquidity, interaction of production resources with liquidity together related to corporate performance and $99 \%$ able to explain corporate performance and $1 \%$ explained by variables not examined in this study.

Investment decisions, liquidity, interaction of investment decisions with liquidity together related to corporate performance and $2.3 \%$ able to explain the corporate performance and $97.7 \%$ explained by variables not examined in this study.

Corporate social responsibility, liquidity, the interaction of Corporate social responsibility with liquidity together related to company performance and $1 \%$ can explain the company's performance and $99 \%$ explained by variables not examined in this study. 
Table 4.3. F test

\begin{tabular}{|r|l|l|}
\hline $\mathrm{F}$ & \multicolumn{1}{|c|}{ Sig } & \multicolumn{1}{c|}{ Note } \\
\hline 5056.525 & $.000^{\mathrm{b}}{ }^{* * *}$ & $\#$ \\
\hline 7910.405 & $.000^{\mathrm{b} * * *}$ & $\#$ \# \\
\hline 2.842 & $.039^{\mathrm{b} * *}$ & \# \# \# \\
\hline .079 & $.971^{\mathrm{b}}$ & \# \# \# \# \\
\hline
\end{tabular}

Source: Data processed (SPSS 20)

Where :

$* * *<=0.001 ; * *<=0.050 ; *<=0.10$.

a. Dependent Variable: CORPORATE PERFORMANCE

\# Predictors: (Constant), CSR, INVESTMENT DECISIONS, PRODUCTION RESOURCES

\# \# Predictors: (Constant), INTERACTION X1 * Z, PRODUCTION RESOURCES, LIQUIDITY

\# \# \# Predictors: (Constant), INTERACTIONS X2 * Z, INVESTMENT DECISIONS, LIQUIDITY \# \# \# \# Predictors: (Constant), INTERACTION X3 * Z, CSR, LIQUIDITY

$\mathrm{F}_{\text {table }}=2.41$

Production resources, investment decisions, corporate social responsibility together influence and significantly affect the corporate performance from a financial perspective (hypothesis 1 is accepted).

Stakeholders of manufacturing companies listed on Indonesian stock exchanges in particular and companies other than manufacturing in general can manage company resources, investment decisions, social responsibility to maximize the achievement of corporate profits so that the company's survival in meeting consumer needs and maintaining business competition can be well maintained .

Table 4.4. T test

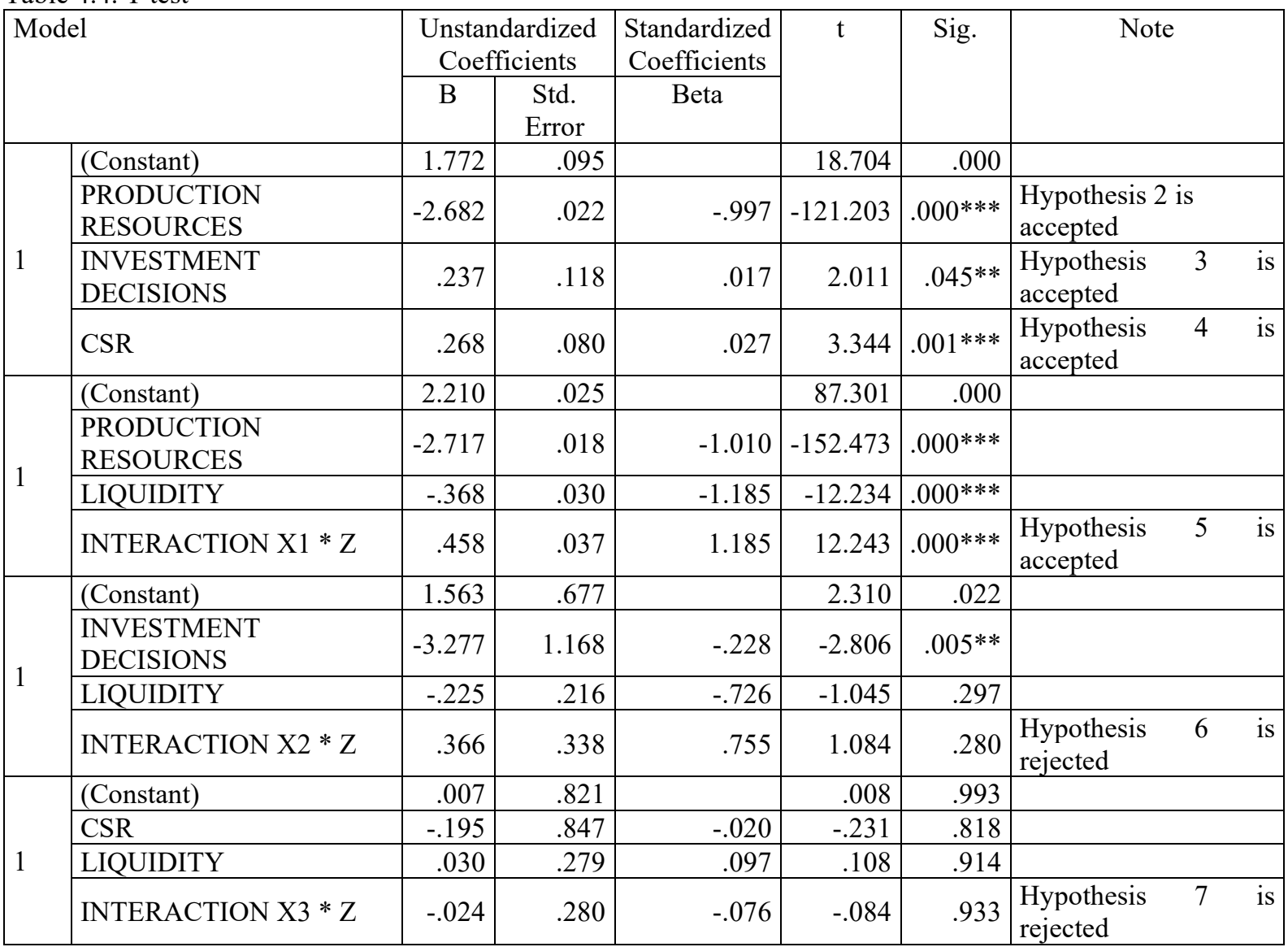

Source: Data processed (SPSS 20)

Where :

$* * *<=0.001 ; * *<=0.050 ; *<=0.10$.

a. Dependent Variable: Corporate Performance

Production resources have an effect and significant on corporate performance (hypothesis 2 is accepted), Productive companies will have better company performance compared to unproductive companies because productive companies will produce higher profits than profits produced by companies that are not productive, this study supports previous research that has been done (Dahan and Srinivasan, 2011; Muthukumar and Nisha, 2014; 
Qudah and Hroot, 2017).

Investment decisions have an effect and significant on corporate performance (hypothesis 3 is accepted), Companies that are able to optimize the capacity to use their assets in creating sales will have a better company performance compared to companies that are not able to optimize the capacity to use their assets because companies that are able to optimize the capacity to use their assets will produce higher profits than profits generated by companies that are unable to optimize the capacity to use their assets, this study supports previous research that has been done (Coban, 2014; Majanga, 2016; Inyiama, et. al, 2017; Mwaniki and Omagwa, 2017), and is in contrast to previous research that has been done (Okwo, et.al., 2012 ; Al Ani, 2014).

Corporate social responsibility have an effect and significant on corporate performance (hypothesis 4 is accepted), Companies that are right in managing corporate social responsibility will have the opportunity to reduce other operational expenses that are greater than CSR realization such as lawsuits, strikes, company closures due to improper handling of waste so that ultimately it can maximize profit compared to companies that are not properly managing corporate social responsibility, they are unable to maximize profits because they will potentially incur greater costs as a result of the company's operations, this study supports previous research that has been done (Zhong and Gao 2017; Samet and Jarboui, 2017; Benlemlih and Bitar, 2018; Cook, et. al., 2018), and is in contrast to previous research (Vance, 1975). ; Branco and Rodriguez, 2006; Kruger, 2015; McWilliams, 2006; Barnet, 2016).

Liquidity moderates the effect of production resources on corporate performance and the moderating nature of liquidity is to strengthen the influence of production resources on corporate performance (hypothesis 5 is accepted), liquidity is indicated by the company's ability to provide financial resources to finance its operations such as fulfilling the company's needs for production resources is an absolute, companies that are able to maintain the level of liquidity at a certain level that is considered safe in financing their operations have the opportunity to maximize profits, this study supports previous research that has been done (Jensen, 1986), and is in contrast to previous research that has been done (Hoshi, et. al., 1991; Audretsch and Elston, 2000; Munoz, 2013; Jafari, 2014; Ogawa, 2015 ).

Liquidity does not moderate the influence of investment decisions on corporate performance and liquidity variables are categorized as potentially moderating / homologizer moderators (hypothesis 6 rejected), Companies that have prospects for growth are companies that reinvest profits earned in the previous period, but on the other side it will cause a conflict of interest between the owner of the company and the management of the company, companies that have poor liquidity will reduce the opportunity for companies to invest in assets and reduce opportunities to maximize profits, this research supports previous research that has been done (Hoshi, et. al., 1991; Audretsch and Elston, 2000; Munoz, 2013; Jafari, 2014; Ogawa, 2015)), and is contrast to opinion (Albrecht et al. , 2011: 554; Harrison, Jr., et.al., 2013: 599).

Liquidity does not moderate the effect of corporate social responsibility on corporate performance and liquidity variables are categorized as potentially moderating / homologizer moderators (hypothesis 7 rejected), The company is able to carry out its social responsibility activities if it has operational funds, the company seeks all legal actions to be able to finance its social responsibility activities by not sacrificing the company's operations, if the owner and management are faced with a choice between the company's operations and social responsibility, it can be ascertained that the owner and management of the company will prefer to run the company's operations and then carry out corporate social responsibility, this study supports previous research that has been done (Vance, 1975; McWilliams, 2006; Barnet, 2016) and is contrast to previous research that has been done (Benlemlih and Bitar, 2018; Cook, et.al., 2018).

\section{Conclusions}

The purpose of this study investigates the effect of simultaneous and partial production resources, investment decision, and corporate social responsibility on company performance and investigate liquidity as a moderating variable on the effect of production resources, investment decisions, corporate social responsibility on corporate performance.

Production Resources, Investment Decisions, Corporate Social Responsibility have an effect and significant to Corporate Performance, Production Resources have a negative and significant effect to Corporate Performance, Investment Decisions have a positive and significant effect to Corporate Performance, Corporate Social Responsibility has a positive and significant effect to Company Performance.

Liquidity moderates the effect of production resources on corporate performance, liquidity does not moderate the influence of investment decisions on corporate performance and liquidity does not moderate the effect of corporate social responsibility to corporate performance.

The implications of this research are 1) prospective investors must consider production resources, investment decisions, corporate social responsibility when joining manufacturing companies, especially manufacturing companies listed on the Indonesia stock exchange for the period of 2016-2018. 2) Stakeholders of manufacturing companies listed on the Indonesian stock exchange must apply the priority principle in business, namely choosing 
to reinvest profits earned in the previous period into the company's fixed assets and after that funding the corporate social responsibility although CSR can be charged by the company but the CSR will be harvested in the future in different forms that can benefit the company.

The limitations in this study are first, the realization of CSR costs of manufacturing companies listed on the Indonesian stock exchange is not entirely disclosed in the company's annual report submitted for publication by the stock exchange management, even though the manufacturing company listed on the Indonesian stock exchange in the current period documents CSR activities carried out and submitted in its annual report. Second, the observation period in this study is relatively short, namely 3 years. Third, observations are only made to one type of company listed on the Indonesia stock exchange.

Suggestions submitted based on the presentation of this study are as follows: 1) The next researcher can conduct research with the same theme in a collection of companies other than manufacturing companies listed on the Indonesia Stock Exchange. 2) Researchers can then add years of observation. 3) The next researcher can add research variables in addition to the variables that have been examined in this study by considering Signal Theory, Agency Theory and Sthewarship Theory (such as variables: stock returns, sustainable dividends, sustainable tax planning). 4) The next researcher can complete the research data for the next study so that the realization of corporate social responsibility (CSR) can be measured in addition to using a dummy measuring instrument.

\section{References}

Aivazian, Varouj A. et.al., (2005). The impact of leverage on firm investment: Canadian evidence, Journal of Corporate Finance 11 (2005), pp. 277-291, doi:10.1016/S0929-1199(03)00062-2.

Al Ani, Mawih K., (2014). Effects of Assets Structure on the Financial Performance: Evidence From Sultanate of Oman, Journal of US-China Public Administration, February 2014, Vol. 11, No. 2, pp. 170-179.

Albrecht, W. Steve, et.al., (2011). Financial Accounting (Eleventh Edition), Mason (USA) : South - Western Cengage Learning.

Audretsch, David B. and Elston, Julie Ann, (2000). Does Firm Size Matter? Evidence on the Impact of Liquidity Constraints of Firm Investment Behavior in Germany, Hamburgisches Welt-Wirtschafts-Archiv (HWWA) Hamburg Institute of International Economics, Discussion Paper 113, pp. 1-26.

Balakrishnan, R., et.al. (2004), Does capacity utilization affect the "stickiness" of cost?, Journal of Accounting, Auditing \& Finance, Vol.19, No.3, pp.283 -299.

Barnett, Michael L., (2016). The Business Case for Corporate Social Responsibility: A Critique and an Indirect Path Forward, Journal Business \& Society, Volume: 58 issue: 1, pp. 167-190. doi.org/10.1177/ 0007650316660044.

Benlemlih, Mohammed dan Bitar, Mohammad, (2018). Corporate Social Responsibility and Investment Efficiency, Journal of Business Ethics Vol 148, Issue 3, pp. 647-671.

Borhan, Halimahton, et.al., (2013). The impact of financial ratios on the financial performance of a chemical company The case of LyondellBasell Industries, World Journal of Entrepreneurship, Management and Sustainable Development, Vol. 10 Issue: 2, pp.154-160, Doi.org/10.1108/WJEMSD-07-2013-0041.

Branco, Manuel Castelo dan Rodrigues, Lucia Lima, (2006). Corporate Social Responsibility and Resource-Based Perspectives, Journal of Business Ethics (2006) 69, pp. 111-132. DOI 10.1007/s10551-006-9071-z.

Chrisman, James J., (2019). Stewardship Theory: Realism, Relevance, and Family Firm Governance, Entrepreneurship Theory and Practice 00(0), pp. 1-16. DOI: 10.1177/1042258719838472.

Coad, Alex and Rao, Rekha, (2012). Firm growth and R\&D expenditure, Economics of Innovation and New Technology, 19:2, pp. 127-145. http://dx.doi.org/10.1080/10438590802472531.

Coad, Alex and Grassano, Nicola, (2018). Firm growth and R\&D investment: SVAR evidence from the world's top R\&D investors, Industry and Innovation, pp. 1-26., DOI: 10.1080/13662716.2018.1459295.

Coban, Serap, (2014). The Interaction Between Firm Growth And Profitability: Evidence From Turkish (Listed) Manufacturing Firms, The Journal of Knowledge Economy \& Knowledge Management / Volume: IX FALL, pp. 73-82.

Cook, Kirsten A., et.al., (2018). The Influence of Corporate Social Responsibility on Investment Efficiency and Innovation, Journal of Business Finance and Accounting, Vol. 46, Issue 3-4, pp. 494-537. Doi.org/10.1111/jbfa.12360.

Cronqvist, H., F. Heyman, M. Nilsson, H. Svaleryd, and J. Vlachos., (2009). Do entrenched managers pay their workers more? The Journal of Finance 64 (1), pp. 309-339.

Dahan, Ely and Srinivasan, V., (2011). The impact of unit cost reductions on gross profit: Increasing or decreasing returns?, IIMB Management Review (2011) 23, pp.131-139. Doi:10.1016/j.iimb.2011.06.004.

Danso, Alebert, et.al., (2017). Leverage and firm investment: the role of information asymmetry and growth, International Journal of Accounting \& Information Management, pp. 1-28., https:// doi.org/10.1108/IJAIM10-2017-0127.

Donaldson, Lex, and Davis, James H., (1991). Stewardship Theory or Agency Theory: CEO Governance and 
Shareholder Returns, Australian Journal of Management, 16, 1, June 1991, pp. 49-64.

Fan, Yun and Liu, Xiaotao (Kelvin), (2016). Misclassifying Core Expenses as Special Items: Cost of Goods Sold or Selling, General, and Administrative Expenses?, Contemporary Accounting Research, Vol. 34, No. 1, Spring, 2017. pp. 400-426. https://doi.org/10.1111/1911-3846.12251.

Franklin John. S, Muthusamy. K, (2011). Impact of Leverage on Firms Investment Decision, International Journal of Scientific \& Engineering Research Volume 2, Issue 4, April-2011, pp. 1-16.

Hoshi, Takeo, et.al., (1991). Corporate Structure, Liquidity, And Investment: Evidence From Japanese Industrial Groups, The Quarterly Journal of Economics, Vol. 106, No. 1, pp. 33-60.

Jafari, Sima, et.al. (2014). The Effect Of Debt, Firm Size And Liquidity On Investment Cash Flow Sensitivity Of Listed Companies In Tehran Stock Exchange, Arabian Journal of Business and Management Review (Nigerian Chapter) Vol. 2, No. 10, 2014, pp. 94-102.

Harrison Jr., Walter T., et.al., (2013). Financial Accounting (Ninth Edition), New Jersey (USA) : Pearson Education, Inc.

Inyiama, Oliver Ike, et.al., (2017). Evaluation of the Relationship between Assets Growth Rate and Financial Performance of Manufacturing Firms in Nigeria, International Journal of Managerial Studies and Research (IJMSR), Volume 5, Issue 10, October 2017, pp. 63-73. http://dx.doi.org/10.20431/2349-0349.0510006.

Jensen, Michael C., (1986). Agency Cost of Free Cash Flow, Corporate Finance, and Takeovers, The American Economic Review, Vol.76, No. 2, hal. 323-329.

Kruger, Philipp, (2015). Corporate Goodness and Shareholder Wealth, Journal of Financial Economics, 115(2), pp. 304-329. Doi.org/10.1016/j.jfineco. 2014.09.008.

Majanga, Byson Beracah, (2016). Corporate CAPEX and market capitalization of firms on Malawi Stock Exchange: an empirical study, Journal of Financial Reporting and Accounting, pp. 1-15. Doi.org/10.1108/JFRA-10-2016-0080.

McWilliams, Abagail, et.al., (2006). Corporate Social Responsibility: Strategic Implications, Journal of Management Studies Vol. 43, Issue 1, pp. 1-18. https://onlinelibrary.wiley.com/toc/14676486/43/1.

Munoz, Francisco., (2013). Liquidity and firm investment: Evidence for Latin America, Journal of Empirical Finance 20 (2013), pp. 18-29. http://dx.doi.org/10.1016/j.jempfin.2012.10.001.

Muthukumar, E. dan K.G. Nisha., (2014). A Study on the Effect of Material Price Fluctuations on the Profitability of Yarn Industry in India (with Special Reference to Precot Meridian Ltd), Research Journal of Finance and Accounting, Vol.5, No.19, 2014, pp. 134-144.

Muzaffar, Bilal, (2015). The Impact of Leverage on the Investment of the Firms, Asian Journal of Humanities and Social Studies Volume 03 - Issue 04, August 2015, pp. 333-341.

Mwaniki, Gladys and Omagwa, Job, (2017). Asset Structure and Financial Performance: A Case of Firms Quoted Under Commercial and Services Sector at the Nairobi Securities Exchange, Kenya, Research Journal of Finance and Accounting, Vol.8, No.4, 2017, pp. 192-200.

Needles, Belverd E., et.al., (2014). Principles Of Accounting (Twelfth Edition), Mason (USA) : South - Western Cengage Learning.

Noreen, E. and Soderstrom, N. (1994). Are Overhead Costs Strictly Proportional to activity? Evidence from hospital departments, Journal of Accounting and Economics vol. 17, No 1-2, pp. 255-278.

Ogawa, Kazuo, (2015). Firm investment, liquidity and bank health: A panel study of Asian firms in the 2000s, Journal of Asian Economics 38 (2015), pp. 44-54. http://dx.doi.org/10.1016/j.asieco.2015.03.002.

Okwo, Ifeoma Mary, et.al., (2012). Investment in Fixed Assets and Firm Profitability: Evidence from the Nigerian Brewery Industry, European Journal of Business and Management, Vol 4, No.20, 2012, pp. 10-17.

Olatunji, T.E. and Tajudeen A.A., (2014). Investment in Fixed Assets and Firm Profitability: Empirical Evidence from the Nigerian Banking Sector. Asian Journal of Social Sciences and Management Studies, Vol. 1., pp. 3247.

Pagano, M., and P. F. Volpin., (2005). The political economy of corporate governance. American Economic Review 95, pp. 1005-1030.

Al-Qudah, Laith Akram Muflih, Al-Hroot, Yusuf Ali Khalaf., (2017). The Implementing Activity-based Costing Technique and Its Impact on Profitability: A Study of Listed Manufacturing Companies in Jordan, International Journal of Economics and Financial Issues, 2017, 7(2), pp. 271-276.

Samet, Marwa, Jarboui, Anis., (2017). How does corporate social responsibility contribute to investment efficiency?, Journal of Multinational Financial Management, Vol. 19, No. 2, pp. 1-35. http://dx.doi.org/10.1016/j.mulfin.2017.05.007.

Slater, Jeffrey, (2013). College Accounting : a Practical Approach (Twelfth Edition), New Jersey (USA) : Perason Education, Inc.

Schillemans, Thomas, and Bjurstrøm, Karl Hagen, (2019). Trust and Verification: Balancing Agency and Stewardship Theory in the Governance of Agencies, International Public Management Journal, pp. 1-35. DOI: 10.1080/10967494.2018.1553807. 
Stulz, R.M., (1990). Managerial Discretion and Optimal Financing Policies, Journal of Financial Economics, Juli, pp.3-28.

Subramanian, S., (2018). Stewardship Theory of Corporate Governance and Value System: The Case of a Familyowned Business Group in India, Indian Journal of Corporate Governance 11(1), pp. 88-102. DOI: $10.1177 / 0974686218776026$.

Timbate, Lukas and Park, Cheong Kyu, (2018). CSR Performance, Financial Reporting, and Investors Perception on Financial Reporting, Sustainability 2018, 10, 522, pp. 1-16. doi:10.3390/su10020522.

Vance, S. C., (1975). Are socially responsible corporations good investment risks? Management Review, 64(8), pp.18-24.

Warren, Carl S., et.al., (2014). Corporate Financial Accounting (Twelfth Edition), Mason (USA) : South - Western Cengage Learning.

Weygandt, Jerry J., et.al., (2012). Accounting Principles (Tenth Edition), New Jersey (USA) : John Wiley \& Sons, Inc.

Wild, John J., (2011). Financial Accounting Fundamentals (Tird Edition), New York (USA) : McGraw - Hill, Inc. Williams, Jan R., et.al., (2012). Financial \& Managerial Accounting: The Basis for Business Decisions (Sixteenth Edition), New York (USA) : McGraw - Hill, Inc.

Zhang, F., et.al., (2017). Roles of Relationships Between Large Shareholders and Managers in Radical Innovation: A Stewardship Theory Perspective, Journal of Product Innovation Management, 2017, pp. 1-18. DOI: 10.1111/jpim.12376.

Zhong, Ma and Gao, Lucia, 2017. Does Corporate Social Responsibility Disclosure Improve Firm Investment Efficiency? Evidence from China", Review of Accounting and Finance, pp. 1-3. Doi.org/10.1108/RAF-062016-0095. 